\section{Mathematical simulation of transient combustion of melted energetic materials}

Zarko V.E.

Voevodsky Institute of Chemical Kinetics and Combustion, Novosibirsk, Russia

E-mail: zarko@kinetics.nsc.ru
The computer code is elaborated for numerical simulation of transient combustion of energetic materials (EM) subjected to the action of time-dependent heat flux and under transient pressure conditions. It allows studying combustion response upon interrupted irradiation (transient pressure) and under action of periodically varied heat flux (pressure) in order to determine stability of ignition transients and parameters of transient combustion. The originally solid EM melts and then evaporates at the surface. It is assumed that chemical transformations occur both in the condensed and gas phases. At the burning surface, the phase transition condition in the form of Clapeyron-Clausius law for equilibrium evaporation is formulated that corresponds to the case of combustion of sublimated or melted EM. The paper contains description of transient combustion problem formulation and several examples of transient combustion modeling. At present time a precise prediction of transient burning rate characteristics is impossible because of the lack of information about magnitude of EM parameters at high temperatures. However, the simulation results bring valuable qualitative information about burning rate behavior at variations in time of external conditions - radiant flux and pressure.

Keywords: combustion simulation; melting; energetic materials; radiant flux; chemica transformations.

\section{Балқитын энергетикалық материалдарының стационарлы емес жануын математикалық модельдеу}

Зарко В.E.

В.В. Воеводский атындағы Химиялық кинетика және жану Институты Новосибирск, Ресей

E-mail:zarko@kinetics.nsc.ru

Уақытқа тәуелді сәулелену ағынға ұшыраған және әртүрлі қысым жағдайларында энергетикалық материалдардың (ЭМ) стационарлық емес жануын сандық модельдеу үшін бағдарлама жасалды. Бағдарлама жану процесінің сәулелену ағынның тоқтауына (өзгерілетін қысым) және жылу ағынының периодикалық әрекетін (қысым) зерттеуге мүмкіндік береді, бұл тұтанудан жануға ауысудың тұрақтылығын және стационарлық емес жанудың параметрлерін анықтайды. Бастапқыда қатты ЭМ балқиды, содан кейін беткі қабаттан бүланады деп болжанады. Химиялық түрленулер конденсацияланған және газ фазаларында да жүреді. Тепе-теңдік булануы үшін Клапейрон-Клаузиус заңымен сипатталған жану бетінде фазалық ауысу жүреді, ол сублимацияланған немесе балқыған ЭМ жану жағдайына сәйкес келеді. Мақалада ЭМ-ның стационарлы емес жану проблемасын тұжырымдау сипаттамасы және осындай мәселелерді модельдеудің бірнеше мысалдары келтірілген. Тұрақты емес жану жылдамдығының сипаттамаларын дәл болжау қазіргі уақытта жоғары температурада ЭМ параметрлері тураль мәліметтердің болмауына байланысты мүмкін емес. Дегенмен, модельдеу нәтижелері сыртқы жағдайлардың өзгеруі кезіндегі ЭМ-ның жану жылдамдығы-сәулелену ағын мен қысым туралы құнды сапалы ақпарат береді.

Түйін сөздер: модельдеу; жану процестері; балқитын энергетикалық материалдар; сәулелену ағындары; химиялық өзгеру.

\section{Математическое моделирование нестационарного горения плавящихся энергетических материалов}

Зарко B.E.

Институт химической кинетики и горения им. В.В. Воеводского, Новосибирск, Росссия E-mail: zarko@kinetics.nsc.ru
Разработана программа для численного моделирования нестационарного горения энергетических материалов (ЭМ) при воздействии на них зависящим от времени потоком излучения и в условиях переменного давления. Программа позволяет изучать отклик процесса горения на отключение потока излучения (переменное давление) и на периодическое действие теплового потока (давления), чтобы определить устойчивость перехода от зажигания к горению и параметры нестационарного горения. Принято, что первоначально твердый ЭМ плавится и затем испаряется с поверхности. Химические превращения происходят как в конденсированной, так и в газовой фазах. На горящей поверхности происходит фазовый переход, описываемый законом Клапейрона-Клаузиуса для равновесного испарения, что соответствует случаю горения сублимирующего или плавящегося ЭМ. Статья содержит описание формулировки проблемы нестационарного горения ЭМ и несколько примеров моделирования таких задач. Точное предсказание характеристик скорости нестационарного горения в настоящее время осуществить невозможно из-за отсутствия данных о параметрах ЭМ при высоких температурах. Тем не менее, результаты моделирования дают ценную качественную информацию о поведении скорости горения ЕМ при вариации внешних условий - потока излучения и давления.

Ключевые слова: моделирование; процессы горения; плавящиеся энергетические материалы; поток излучения; химические превращения. 


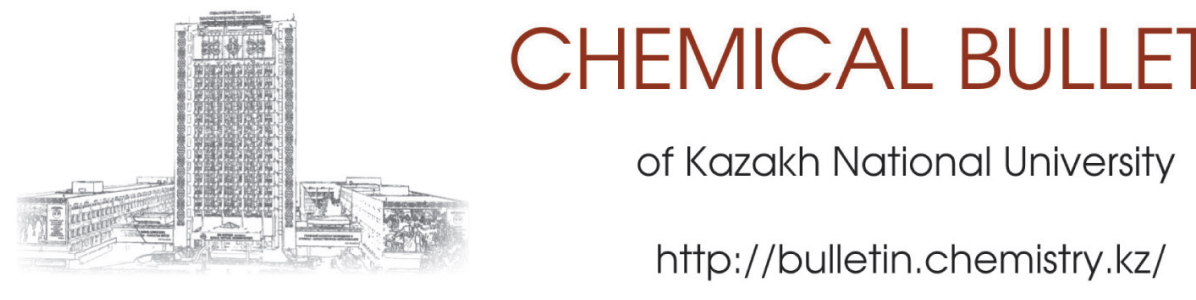

UDC 536.46

https://doi.org/10.15328/cb1079

\section{Mathematical simulation of transient combustion of melted energetic materials}

\section{Zarko V.E.}

Voevodsky Institute of Chemical Kinetics and Combustion, Novosibirsk, Russia

E-mail: zarko@kinetics.nsc.ru

\section{Introduction}

Transient combustion of energetic materials (EM) takes place during ignition and extinction events as well as in response to variation of environmental conditions. Experimental studying of EM combustion behavior in many cases is the time and money consuming deal, especially in the case of non-stationary processes. Therefore it is reasonable to elaborate theoretical methods for simulating the combustion behavior of EMs, and this work has beeen extensively performed over the world starting from $1970^{\text {th }}$. In the beginning, the researchers dealt with the global reaction schemes [1,2] and later many attempts were made on developing and use of detailed chemical mechanisms of exothermic reactions in the combustion wave [3-10]. Unfortunately, there exists a great problem of obtaining the correct parameters of chemical reactions and values of EM properties at high temperatures and this makes questionable the accuracy of calculation results. Actually, till now the researchers are urged to use global reaction mechanisms to solve the problem of transient combustion behavior and for adequate modeling it is necessary to take into account the physical processes accompanying the combustion process. For this end it was developed so called computer code CTEM (Combustion Transients of Energetic Materials) [11] intended for mathematical simulation of transient burning characteristics of melted and evaporated EM subjected to the action of timedependent heat flux or transient pressure. Within the code, it was taken account of radiation energy absorption both in the condensed and gas phases. CTEM allows studying the combustion response in conditions of interrupted irradiation (varied pressure) and under periodically varying heat flux (pressure) action in order to determine stability of ignition transients and parameters of non-stationary combustion.

\section{Problem formulation}

The originally solid EM melts and then evaporates at the surface. It is assumed that the radiant flux is absorbed in the bulk of EM according to the Bouguer-Lambert-Beer law. Depending on the EM optical properties the depth of radiation penetration is varied. It is also assumed that the chemical

\footnotetext{
Nomenclature

$\mathrm{t}$ - time [s],

$x$ - spatial coordinate $[\mathrm{m}]$,

$\mathrm{V}$ - burning rate $[\mathrm{m} / \mathrm{s}]$

$\mathrm{V}^{\mathrm{c}}-$ gas velocity $[\mathrm{m} / \mathrm{s}]$,

$\mathrm{T}$ - temperature $[\mathrm{K}]$,

$\rho$-density $\left[\mathrm{kg} / \mathrm{m}^{3}\right]$,

$\mathrm{p}$ - pressure [MPa],

$y_{i}-$ mass fraction of species $i$

$x_{i}-$ molar fraction of species $i$,

$\mathrm{C}$ - specific heat of condensed phase $[\mathrm{kJ} /(\mathrm{kg} \cdot \mathrm{K})]$,

$\mathrm{C}_{\mathrm{pi}}$ - constant-pressure heat capacity of species $\mathrm{i}[\mathrm{kJ} /(\mathrm{kg} \cdot \mathrm{K})]$,

$\lambda^{\mathrm{pi}}$ - thermal conductivity $[\mathrm{kJ} /(\mathrm{m} \cdot \mathrm{s} \cdot \mathrm{K})]$,

$\mathrm{Q}$ - heat release per unit mass $[\mathrm{kJ} / \mathrm{kg}]$,

$\mathrm{M}_{\mathrm{i}}$ - molecular weight of species i $[\mathrm{kg} / \mathrm{kmol}]$,

$\mathrm{R}$ - universal gas constant $[\mathrm{kJ} /(\mathrm{kmol} \cdot \mathrm{K})]$,

$\mathrm{L}$ - latent heat of evaporation [kJ/kg],

A - pre-exponential factor of rate constant,
}

E - energy of activation $[\mathrm{kJ} / \mathrm{kmol}]$

$\mathrm{D}-$ diffusion coefficient $\left[\mathrm{m}^{2} / \mathrm{s}\right]$,

$\mathrm{q}$ - external heat flux $\left[\mathrm{kJ} /\left(\mathrm{m}^{2} \cdot \mathrm{s}\right)\right]$

$f-$ frequency of oscillations $[1 / \mathrm{s}]$,

$\alpha_{\mathrm{g} i}\left[\mathrm{~kg} / \mathrm{m}^{2}\right], \alpha_{\mathrm{c} i}[1 / \mathrm{m}]$ - absorption coefficients for gas phase and

condensed phase in the Bouguer-Lambert-Beer law.

\section{Subscripts}

c - parameters of the condensed phase,

I - parameters of the liquid phase,

$1,2,3$ - species in the gas phase (vapor, intermediate product, final combustion product, correspondingly),

$\mathrm{s}$ - energetic material surface,

$\mathrm{m}-$ melting point

$0-$ corresponds to initial conditions.

Variables without index correspond to the bulk of gas phase. 
transformations proceed both in the condensed and gas phases. At the burning surface, the phase transition condition in the form of Clapeyron-Clausius law for equilibrium evaporation is formulated that corresponds to the case of combustion of sublimated or melted EM. The calculation domain is shown in Figure 1 . The coordinate $x=x_{m}$ corresponds to the boundary between the liquid phase and solid phase domains with the temperature of condensed phase transition (melting) being equal to $T_{m}$

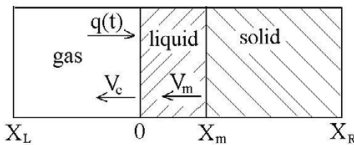

Figure 1 - Sketch of calculation domain

When choosing movable coordinate system $(x, t)$ attached to the burning surface, one obtains the following system of equations describing heat propagation in the condensed phase:

a) solid phase $\left(x_{m} \leq x \leq x_{R}\right)$

$$
C_{c} \rho_{c}\left(\frac{\partial T_{c}}{\partial t}-V_{c} \frac{\partial T_{c}}{\partial x}\right)=\lambda_{c} \frac{\partial^{2} T_{c}}{\partial x^{2}}+q(0, t) \sum_{j=1}^{N} \delta_{c j} \alpha_{c j} \exp \left(-\alpha_{c j} x\right)
$$

at the boundaries

$$
T_{c}(x, 0)=T_{0}, \quad T_{c}\left(x_{m}, t\right)=T_{m}, \quad\left(\frac{\partial T_{c}}{\partial x}\right)_{x=x_{R}}=0,
$$

b) liquid phase $\left(0 \leq x \leq x_{m}\right)$

$$
\begin{gathered}
C_{l} \rho_{c}\left(\frac{\partial T_{c}}{\partial t}-V_{c} \frac{\partial T_{c}}{\partial x}\right)=\lambda_{l} \frac{\partial^{2} T_{c}}{\partial x^{2}}+\Phi_{c 1}+\Phi_{c 2}+q(0, t) \sum_{j=1}^{N} \delta_{c j} \alpha_{c j} \exp \left(-\alpha_{c j} x\right) \\
\rho_{c}\left(\frac{\partial y_{c}}{\partial t}-V_{c} \frac{\partial y_{c}}{\partial x}\right)=-\omega_{c 1}-\omega_{c 2}
\end{gathered}
$$

Here $\mathrm{q}(0, \mathrm{t})=\mathrm{q}_{0} \sum_{\mathrm{j}}^{\mathrm{N}} \delta_{\mathrm{gij}} \exp \left(-\alpha_{\mathrm{gij}} \int_{0}^{0} \rho \mathrm{y}_{1} \mathrm{dx}\right)$ - radiant flux impinging the burning surface $\mathrm{j}_{\mathrm{j}}^{\mathrm{j}}$ with account of its partial absorbance in a gas phase,

$$
\Phi_{\mathrm{ci}}=\mathrm{Q}_{\mathrm{ci}} \omega_{\mathrm{ci}}, \quad \omega_{\mathrm{ci}}=\mathrm{A}_{\mathrm{ci}} \mathrm{P}_{\mathrm{c}} \mathrm{y}_{\mathrm{c}} \exp \left(-\mathrm{E}_{\mathrm{ci}} / \mathrm{RT}_{\mathrm{c}}\right), \quad \mathrm{i}=1,2
$$

at the boundary

$$
\begin{aligned}
y_{c}\left(x_{m}, t\right) & =1, \quad T_{c}(x, 0)=T_{0}, \quad T_{c}\left(x_{m}, t\right)=T_{m}, \quad\left[\lambda\left(\frac{\partial T_{c}}{\partial x}\right)\right]_{x=x_{m}+0}-\left[\lambda\left(\frac{\partial T_{c}}{\partial x}\right)\right]_{x=x_{m}-0}=\left(V_{m}+V_{c}\right) L_{m} \rho_{c}, \\
\frac{d x_{m}}{d t} & =V_{m} .
\end{aligned}
$$

Let's assume further that the condensed phase reaction produces intermediate product and in the gas phase there are 3 components: vapor $Y_{1}$, intermediate product $Y_{2}$, and final combustion product $Y_{3}$. Decomposition of vapor as well as chemical conversion of intermediate product obey the reactions of an arbitrary order. The scheme of chemical transformations is shown in Figure 2.

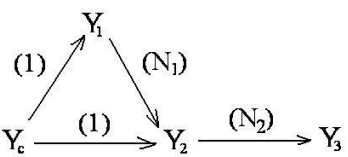

Figure $\mathbf{2}$ - Scheme of chemical transformations by burning EM

Here the values into brackets mean the order of reaction. The temperature of the components is uniform at the given point of space. It is assumed that the absorbance of radiant energy presumably occurs in the vapor which is composed of the substances with large molecular mass.

The system of equations for the gas phase is as follows ( $x_{L}$ $\leq x \leq 0)$ :

$$
\begin{gathered}
\mathrm{C}_{\mathrm{p}} \rho\left(\frac{\partial \mathrm{T}}{\partial \mathrm{t}}-\left(\mathrm{V}-\mathrm{V}_{\mathrm{c}}-\sum_{\mathrm{i}=1}^{3} \frac{\mathrm{C}_{\mathrm{pi}}}{\mathrm{C}_{\mathrm{p}}} \mathrm{D}_{\mathrm{i}} \frac{\partial \mathrm{y}_{\mathrm{i}}}{\partial \mathrm{x}}\right) \frac{\partial \mathrm{T}}{\partial \mathrm{x}}\right)=\frac{\partial}{\partial \mathrm{x}}\left(\lambda \frac{\partial \mathrm{T}}{\partial \mathrm{x}}\right)+\Phi_{1}+\Phi_{2}+ \\
+\mathrm{q}_{0} \rho \mathrm{y}_{1} \sum_{\mathrm{j}=1}^{\mathrm{N}} \delta_{\mathrm{gj}} \alpha_{\mathrm{gj}} \exp \left(-\alpha_{\mathrm{gg}} \int_{\mathrm{x}_{\mathrm{L}}}^{\mathrm{x}} \rho \mathrm{y}_{1} \mathrm{dx}\right)+\mathrm{W}, \\
\rho\left(\frac{\partial y_{1}}{\partial t}+\left(V-V_{c}\right) \frac{\partial y_{1}}{\partial x}\right)=\frac{\partial}{\partial x}\left(\rho D_{1} \frac{\partial y_{1}}{\partial x}\right)-\omega_{1}, \\
\rho\left(\frac{\partial y_{2}}{\partial t}+\left(V-V_{c}\right) \frac{\partial y_{2}}{\partial x}\right)=\frac{\partial}{\partial x}\left(\rho D_{2} \frac{\partial y_{2}}{\partial x}\right)-\omega_{2}+\omega_{1}, \\
\frac{\partial \rho}{\partial t}-V_{c} \frac{\partial \rho}{\partial x}+\frac{\partial(\rho V)}{\partial x}=0, \\
\frac{1}{\mathrm{M}}=\left(\frac{\mathrm{y}_{1}}{\mathrm{M}_{1}}+\frac{\mathrm{y}_{2}}{\mathrm{M}_{2}}+\frac{\mathrm{y}_{3}}{\mathrm{M}_{3}}\right), \quad \Phi_{1}=\mathrm{Q}_{1} \omega_{1}, \quad \Phi_{2}=\mathrm{Q}_{2} \omega_{2}
\end{gathered}
$$

$\omega_{1}=A_{1}\left(\rho y_{1}\right)^{N_{1}} \exp \left(-E_{1} / R T\right), \omega_{2}=A_{2}\left(\rho y_{2}\right)^{N_{2}} \exp \left(-E_{2} / R T\right)$,

$$
\mathrm{W}=\text { const }=\mathrm{qz} \text { at time } \mathrm{tz} \leq \mathrm{t} \leq \mathrm{tz}_{2} \text {, and } \mathrm{x}_{\mathrm{L}} \leq \mathrm{x} \leq 0
$$$$
\mathrm{W}=0 \text { in all other cases and at the boundaries }
$$

$$
\begin{gathered}
\mathrm{T}(\mathrm{x}, 0)=\mathrm{T}_{0}, \quad \mathrm{y}_{1}(\mathrm{x}, 0)=\mathrm{y}_{2}(\mathrm{x}, 0)=0, \quad \frac{\partial \mathrm{T}}{\partial \mathrm{x}}=\frac{\partial \mathrm{y}_{1}}{\partial \mathrm{x}}=\frac{\partial \mathrm{y}_{2}}{\partial \mathrm{x}}=0 \\
\text { at } x=x_{L}
\end{gathered}
$$

The term $W$ in Equation 4 depicts the action of externally imposed heating in the gas phase in order to trigger the ignition of gases above the EM surface. The gas heater acts during period of time $\left(\mathrm{tz}_{1}, \mathrm{tz}_{2}\right)$ in spatial domain $\left(\mathrm{x}_{\mathrm{L}}, \mathrm{x}_{\mathrm{R}}\right)$. Mass fraction of the combustion products and their effective diffusion coefficient 
are determined on the basis of mass conservation equation and condition of zero sum of individual diffusion fluxes:

$$
\mathrm{y}_{1}+\mathrm{y}_{2}+\mathrm{y}_{3}+1, \quad \mathrm{D}_{1} \frac{\partial \mathrm{y}_{1}}{\partial \mathrm{x}}+\mathrm{D}_{2} \frac{\partial \mathrm{y}_{2}}{\partial \mathrm{x}}+\mathrm{D}_{3} \frac{\partial \mathrm{y}_{3}}{\partial \mathrm{x}}=0
$$

In order to solve numerically the problem (1-9) a spatial domain $\mathrm{x}_{L}<\mathrm{x}<\mathrm{x}_{\mathrm{R}}$ should be chosen on the basis of physical considerations or numerical experiment.

It is assumed that the pressure and radiant flux $q_{0}$ can vary in time. The following $p$ - $t$ diagram (Figure 3 ) picturizes temporal behavior of pressure.

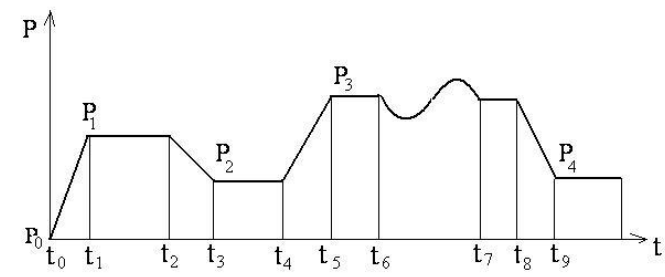

Figure 3-P-t diagram used in calculations

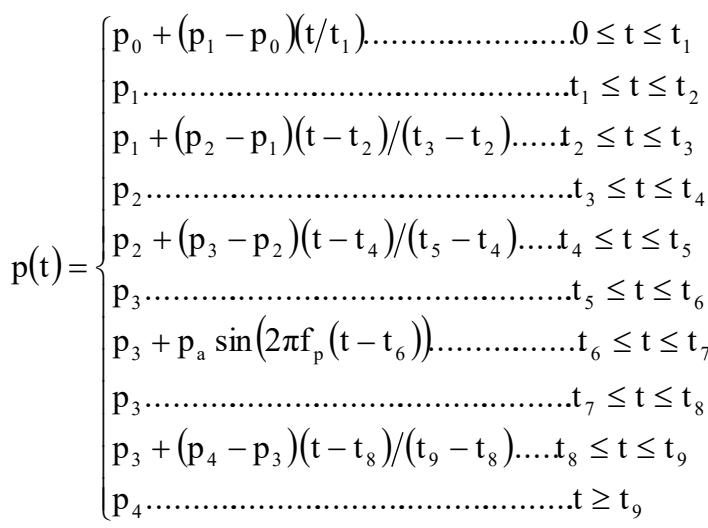

When using CTEM it is possible to study burning rate behavior during combustion transients as well as the response of burning rate to oscillating pressure or transient heat flux.

\section{Transport coefficients for the gas species}

The transport coefficients for gas mixture are determined on the basis of molecular gas theory. The effective value of thermal conductivity for gas mixture is calculated by the formulae of Mason and Saxena [12].

$$
\begin{gathered}
\lambda=\sum_{\mathrm{i}=1}^{3} \frac{\lambda_{\mathrm{i}}}{1+1.065 \sum_{\mathrm{k}=1}^{3} \mathrm{G}_{\mathrm{ik}} \frac{\mathrm{x}_{\mathrm{k}}}{\mathrm{x}_{\mathrm{i}}}} \\
\mathrm{G}_{\mathrm{ik}}=\frac{\left(1+\left(\lambda_{\mathrm{i}} / \lambda_{\mathrm{k}}\right)^{1 / 2}\left(\mathrm{M}_{\mathrm{i}} / \mathrm{M}_{\mathrm{k}}\right)^{1 / 4}\right)^{2}}{2 \sqrt{2} \sqrt{1+\mathrm{M}_{\mathrm{i}} / \mathrm{M}_{\mathrm{k}}}}
\end{gathered}
$$

$$
\lambda_{\mathrm{i}}=\mathrm{A}_{\lambda_{\mathrm{i}}}+\mathrm{B}_{\lambda_{\mathrm{i}}} \mathrm{T}, \quad \mathrm{x}_{\mathrm{i}}=\mathrm{y}_{\mathrm{i}} \mathrm{M} / \mathrm{M}_{\mathrm{i}},
$$

Here $A_{\lambda i}$ and $B_{\lambda i}$ are tabulated empirical constants. The specific heat for gas mixture is determined additively by formulae

$$
\begin{aligned}
& \mathrm{C}_{\mathrm{p}}=\sum_{\mathrm{i}=1}^{3} \mathrm{y}_{\mathrm{i}} \mathrm{C}_{\mathrm{pi}} \\
& \mathrm{C}_{\mathrm{pi}}=\mathrm{A}_{\mathrm{cpi}}+\mathrm{B}_{\mathrm{cpi}} \mathrm{T}
\end{aligned}
$$

where $\mathrm{A}_{\mathrm{cpi}}$ and $\mathrm{B}_{\mathrm{cpi}}$ are tabulated constants. The values of effective diffusion coefficients for vapor and combustible gas are determined by the formulae Wilke [13] (as mentioned above, for final combustion product this value is calculated using condition of zero sum of diffusion fluxes of components):

$$
\mathrm{D}_{\mathrm{i}}=\left(1-\mathrm{x}_{\mathrm{i}}\right) / \sum_{\substack{\mathrm{k}=1 \\ \mathrm{k} \neq \mathrm{i}}}^{3} \frac{\mathrm{x}_{\mathrm{k}}}{\mathrm{D}_{\mathrm{ik}}}
$$

$$
\mathrm{D}_{\mathrm{ik}}=2.628 \cdot 10^{-3} \frac{\mathrm{T} \sqrt{\mathrm{T}\left(\mathrm{M}_{\mathrm{i}}+\mathrm{M}_{\mathrm{k}}\right) / 2 \mathrm{M}_{\mathrm{i}} \mathrm{M}_{\mathrm{k}}}}{\mathrm{p} \Omega_{\mathrm{ik}}^{(1,1)^{*}} \mathrm{~T}_{\mathrm{ik}}^{*} \sigma_{\mathrm{ik}}^{2}}
$$

The collision integral is calculated by using approximation offered by Anfimov [14]

$$
\begin{gathered}
\Omega_{\mathrm{ik}}^{(1,1) *} \mathrm{~T}_{\mathrm{ik}}^{*}=1.074\left(\frac{\mathrm{kT}}{}\right)^{-0.1604} \\
\sigma_{\mathrm{ik}}=\left(\sigma_{\mathrm{i}}+\sigma_{\mathrm{k}}\right) / 2
\end{gathered}
$$

Here $\varepsilon_{\mathrm{ik}} / \mathrm{k}$ and $\varepsilon_{\mathrm{ik}}$ are the parameters of potential energy of molecules (Lennard-Jones potentials).

\section{Combustion modelling}

It is assumed that the energetic material is solid which is melted and evaporated along with 2 chemical transformations in the condensed phase described by the reaction of the $1^{\text {th }}$ order. One reaction can be exothermic and another reaction can be endothermal. There is no temperature discontinuity at the surface, i.e., $T=T_{c}=T_{s}$ at $x=0$. At the surface of $E M$ the equilibrium evaporation occurs which obeys the ClapeyronClausius equation. In the gas phase, there are 2 reactions of arbitrary order. Boundary conditions are as follows:

$$
\begin{gathered}
\lambda\left(\frac{\partial T}{\partial x}\right)_{x=-0}=\lambda_{c}\left(\frac{\partial T_{c}}{\partial x}\right)_{x=+0}+q_{r}(t)-y_{c} \rho_{c} V_{c} L \\
-\rho\left(V-V_{c}\right) y_{1}+D_{1} \rho \frac{\partial y_{1}}{\partial x}=\rho_{c} V_{c} y_{c}
\end{gathered}
$$




$$
\begin{gathered}
-\rho\left(V-V_{c}\right) y_{2}+D_{2} \rho \frac{\partial y_{2}}{\partial x}=\rho_{c} V_{c}\left(1-y_{c}\right) \\
-\rho\left(V-V_{c}\right)=-\rho_{c} V_{c}, \quad y_{1}=\frac{M_{1}}{M} \exp \left[-\frac{L_{1}}{R}\left(\frac{1}{T_{s}}-\frac{1}{T_{b}}\right)\right]
\end{gathered}
$$

To illustrate the application of CTEM to transient combustion simulation let we analyze the response of the burning rate to oscillating pressure. This is an important characteristic of dynamic behavior of the energetic material burning rate in a rocket motor. If the response function $\mathrm{Rp}=\mathrm{dlnV}_{\mathrm{c}} / \mathrm{dp}$ is larger than unity, it may lead to failure of the motor in the case of appearance oscillations with given frequency. Figure 4 shows the results of calculations for chosen EM at $P=70$ atm and $\Delta p / p=0.02$.

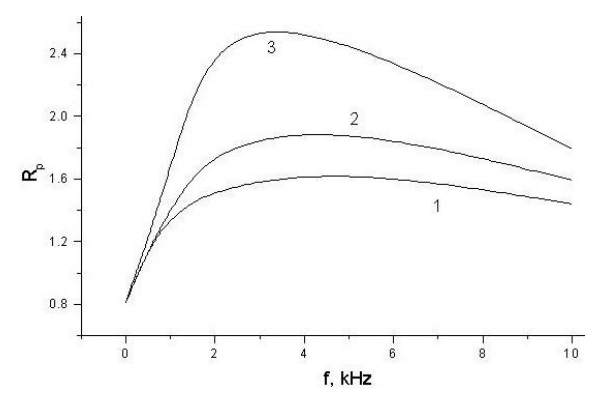

$1-T_{m}=580 \mathrm{~K}, \quad Q_{m}=38 \mathrm{cal} / \mathrm{g} ; \quad 2-T_{m}=480 \mathrm{~K}, \quad Q_{m}=38 \mathrm{cal} / \mathrm{g} ;$ $3-T_{m}=480 \mathrm{~K}, Q_{m}=60 \mathrm{cal} / \mathrm{g}$.

Figure 4 - Value of Rp vs frequency of pressure oscillations at different temperatures and heat of melting

An example of numerical simulation of combustion behavior during transition from ignition to self-sustaining combustion is shown in Figures 5-7. It is known that if a high amplitude radiant flux $q(0, t)=q_{r}$ is abruptly terminated, it leads to extinction of burning EM. Therefore in these calculations we gradually decreased the radiant flux intensity (after $\mathrm{t}=0.05 \mathrm{~s}$ ) up to zero level and analyzed the burning rate $V_{c}=r_{b}$ behavior in time. Surface temperature $T_{s}$ just slightly decreased and main changes were observed with the burning rate. It is impossible to predict such behavior without making numerical simulation because it is the result of complex play of physical and chemical phenomena. Obviously, during initial heating by powerful radiant flux the steep temperature gradient in the condensed phase is formed and in course of heating by decreasing heat flux the temperature profile in the subsurface layer is modified. Thus, the amount of heat in subsurface layer is increased and at the moment $\mathrm{t}=0.45 \mathrm{~s}$ the sort of thermal explosion in this layer occurs and burning rate is sharply increased. After burnout of subsurface layer the burning rate is temporally decreased and then increased $(t=0.5 \mathrm{~s})$. After that a successful transition to self-sustaining combustion finally occurs.

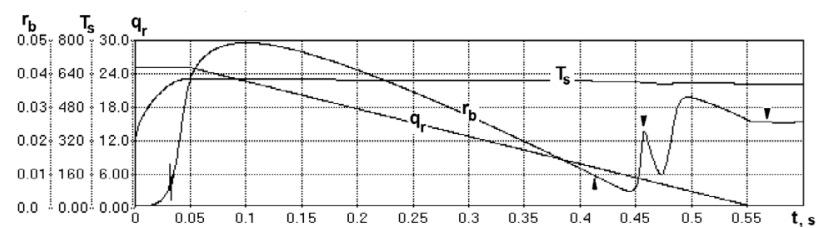

Figure 5 - Temporal behavior of combustion wave characteristics during ignition of EM

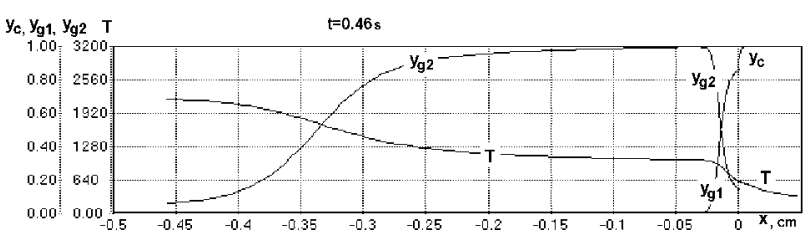

Figure 6-Spatial distribution of the combustion wave parameters at $\mathrm{t}=0.46 \mathrm{~s}$

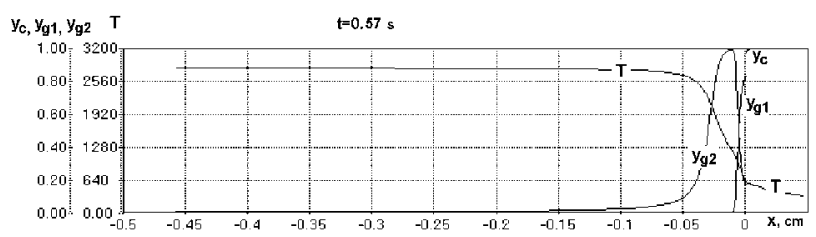

Figure 7 - Spatial distribution of the combustion wave parameters at $\mathrm{t}=0.57 \mathrm{~s}$

It is necessary to note that during transient combustion periods the spatial distribution of the combustion wave parameters differs of those in self-sustaining combustion. The CTEM allows examining the spatial distributions at various moments of time. Figure 6 shows at the time instant $t=0.46 \mathrm{~s}$ the temperature profile $T(x)$ and mass fractions of condensed material $Y_{c^{\prime}}$, vapor $Y_{g 1}$ and intermediate combustion products $Y_{g 2}$. It is seen that the reaction in gas phase with formation of final products proceeds at finite distance from the surface (about $0.25-0.40 \mathrm{~mm}$ ) and temperature in gas is below the maximal value.

Analysis of these pictures shows that the flame gradually approaches the ignited surface and spatial distributions after establishing stable combustion demonstrate the steep gradient of temperature profile, fast reaction in the vapor and gas in the close vicinity of the burning surface. The ignition behavior of EM with formation of flame initially at the finite distance from the ignited surface has been observed in experiments with nitramines and double base propellants.

\section{Conclusion}

The paper deals with the numerical simulation of transient combustion of melted and evaporated EM. This corresponds to 
the behavior of numerous contemporary EMs which melt upon heating and produce vapor and intermediate combustion products. The simulation is performed with use of original computer code CTEM which takes into account the physical and chemical transformations in the condensed and gas phases. The correctness of numerical calculations by this code has been evaluated via comparison with the results of calculating the surface temperature in the case of "inert" heating via use of available analytical formulae. It was found that the difference between calculated temperature values did not exceed $1 \%$. The precise combustion modeling could not be done at present time due to the lack of data about the EM physical properties and kinetic data for global reactions at high temperatures. However, systematic mathematical modeling with use of CTEM may give important and useful qualitative information about combustion behavior of existing EM.

\section{Acknowledgements}

The financial support by the Russian Foundation for Basic Research (Grant \#16-29-01029) is greatly acknowledged.

\section{References (GOST)}

1 Miller M.S. In search of an idealized model of homogeneous solid propellant combustion // Combust Flame. - 1982. - Vol.46. - P.51-73.

2 Vilyunov V.N., Zarko V.E. Ignition of solids. - New York: Elsevier Science Publishers, 1989.

3 Ermolin N.E. Model for chemical reaction kinetics in perchloric acid-ammonia flames // Combust Explosion Shock Waves. 1995. - Vol.31(5). - P.555-565.

4 Liau Y.-C., Yang V. Analysis of RDX monopropellant combustion with two-phase subsurface reactions // Journal of Propulsion and Power. - 1995. - Vol.11(4). - P.729-39

5 Davidson J.E., Beckstead M.W. Improvements to steady state combustion modeling of cyclotrimethylenetrinitramine // Journal of Propulsion and Power. - 1997. - Vol.13(3). - P.375-83.

6 Beckstead M.W. Overview of combustion mechanisms and flame structures for advanced solid propellants. In: Yang V., Brill T.B., Ren W.Z. (Eds.) Solid propellant chemistry, combustion, and motor interior ballistics. - Progress in Astronautics and Aeronautics, AIAA, New York, USA. - 2002. - P.267-285.

7 Puduppakkam K.V., Beckstead M.W. Combustion modeling of glycidyl azide polymer with detailed kinetics // Combustion Science and Technology. - 2005. - Vol.177(9). - P.1661-1697

8 Beckstead M.W., Puduppakkam K., Thakre P., Yang V. Modeling of combustion and ignition of solid-propellant ingredients // Progress in Energy and Combustion Science. - 2007. - Vol.33. - P.497-551.

9 Tian Zh., Zhang Zh., Lu F., Chen R. Modeling and simulation of laser-induced ignition of RDX using detailed chemical kinetics // Propellants, Explosives, Pyrotechnics. - 2014. - Vol.39. - P.838-843.

10 Gallier S., Ferrand A., Plaud M. Three-dimensional simulations of ignition of composite solid propellants // Combustion and Flame. - 2016. - Vol.173. - P.2-15

11 Gusachenko L.K., Zarko V.E., Rychkov A.D. Effect of melting on dynamic combustion behavior of energetic materials // Journal of Propulsion and Power. - 1999. - Vol.15(6). - P.816-822.

12 Mason E.A., Saxena S.C. Approximate formula for the thermal conductivity of gas mixture // Physics of Fluids. - 1958. Vol.1(5). - P.361-369.

13 Wilke C.R. Diffusional properties of multicomponent gases // The Journal of Chemical Physics. - 1950. - Vol.18. - P.517-522.

14 Anfimov N.A. Laminar boundary layer in a multicomponent gas mixture [Laminarnyy pogranichnyy sloy v mnogokomponentnoy smesi gazov] // Bulletin of the USSR Academy of Sciences, Mechanics and Mechanical Engineering [lzvestia AN SSSR, Mechanica i Mashinostroenie]. - 1962. - Vol.1. - P.25-319.

\section{References}

1 Miller MS (1982) Combust Flame 46:51-73. https://doi.org/10.1016/0010-2180(82)90006-2

2 Vilyunov VN, Zarko VE (1989) Ignition of solids. New York: Elsevier Science Publishers. ISBN 978-0444872890

3 Ermolin NE (1995) Combust Explos Shock Waves 31(5):555-565. https://doi.org/10.1007/BF00743807

4 Liau Y-C, Yang V (1995) J Propul Power 11(4):729-39. https://doi.org/10.2514/3.23898

5 Davidson JE, Beckstead MW (1997) J Propul Power 13(3):375-83. https://doi.org/10.2514/2.5194

6 Beckstead MW (2000) An overview of combustion mechanisms and flame structures for advanced solid propellants. In: Solid propellant chemistry, combustion, and motor interior ballistics, ed. by Yang V, Brill TB, Ren WZ. P.267-285. Progress in Astronautics and Aeronautics, AIAA, New York, USA. https://doi.org/10.2514/6.2000-3325

7 Puduppakkam KV, Beckstead MW (2005) Combust Sci Technol 177(9):1661-1697. https://doi.org/10.1080/0010220059095-6740 
8 Beckstead MW, Puduppakkam K, Thakre P, Yang V (2007) Prog Energ Combuste 33:497-551. https://doi.org/10.1016/j. pecs.2007.02.003

9 Tian Zh, Zhang Zh, Lu F, Chen R (2014) Propell Explos Pyrot 39:838-843. https://doi.org/10.1002/prep.201400064

10 Gallier S, Ferrand A, Plaud M (2016) Combust Flame 173:2-15. https://doi.org/10.1016/j.combustflame.2016.07.012

11 Gusachenko LK, Zarko VE, Rychkov AD (1999) J Propulsion Power 15: 816-822. https://doi.org/10.2514/2.5501

12 Mason EA, Saxena SC (1958) Phys Fluids 1:361-369. https://doi.org/10.1063/1.1724352

13 Wilke CR (1950) J Chem Phys 18:517-522. https://doi.org/10.1021/ie50483a022

14 Anfimov NA (1962) Bulletin of the USSR Academy of Sciences, Mechanics and Mechanical Engineering [Izvestia AN SSSR, Mechanica i Mashinostroenie] 1:25-319. (In Russian) 